\title{
Carbon Taxes and the Composition of New Passenger Car Sales in Europe
}

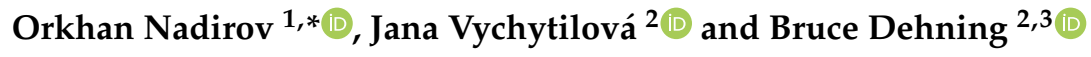 \\ 1 School of Public and International Affairs, ADA University, 61 Ahmadbay Agha-Oglu Street, \\ Baku 1008, Azerbaijan \\ 2 Faculty of Management and Economics, Tomas Bata University in Zlin, Mostní 5139, 76001 Zlín, \\ Czech Republic; vychytilova@utb.cz (J.V.); dehning@utb.cz or bdehning@chapman.edu (B.D.) \\ 3 Argyros School of Business and Economics, Chapman University, One University Drive, \\ Orange, CA 9166, USA \\ * Correspondence: onadirov@ada.edu.az
}

Received: 5 August 2020; Accepted: 4 September 2020; Published: 6 September 2020

\begin{abstract}
This paper examines the effectiveness of implementing carbon taxes to reduce carbon dioxide emissions from transport. Using the system Generalized Method of Moments estimator, we utilize cross-country analysis for the first time to study the impact of carbon taxes on the composition of petrol versus diesel passenger cars sold in 17 countries over the period 2013-2017. The results suggest that increasing carbon taxes affects consumer behavior, causing a significant shift from petrol to diesel fuel vehicles, controlling for factors such as the price of passenger cars, fuel price, interest rates, income level, population density, inflation, and vehicle stock.
\end{abstract}

Keywords: new passenger car sales; carbon tax; climate policy; automobile industry; socioeconomic factors; GMM

\section{Introduction}

Climate change is widely considered one of the most important economic and political challenges of our times. Increasing concentrations of greenhouse gases in the atmosphere are causing rising global temperatures. The reduction in carbon dioxide $\left(\mathrm{CO}_{2}\right)$ emissions in a technically and economically feasible way [1] is increasingly in the interest of governments and is also gaining a substantial role across economic, environmental, political, and social discussions [2].

In the last decade, the EU has called for a significant reduction in world greenhouse gas emissions, aiming to limit the increase in average temperature to less than $2{ }^{\circ} \mathrm{C}$. This goal was approved and agreed to by the international community. In 2005, the EU set-up the world's first emissions trading system (EU ETS) to combat climate change by reducing greenhouse gas emissions in a cost-effective way. The EU ETS puts a price on carbon across all 28 EU member states, plus Iceland, Norway, and Liechtenstein. The biggest scheme to date, it has substantially affected the ongoing global climate policy debate, carbon-emitting practices, and attracted enormous attention in the literature (for the recently examined effect of the EU ETS on the economy, see [3]; on stock returns in Germany and UK, see [4]). Even though the EU ETS has been in place for over a decade, "transport fuels in the EU are not included in the ETS" [5].

According to European Environment Agency (EEA data) statistics, the transport sector contributed to $24.4 \%$ of total EU-28 greenhouse gas emissions in 2013, $19.4 \%$ above 1990 levels. This makes a substantial reduction in emissions from vehicles an urgent necessity to meet the long-term targets set in the 2011 Transport White Paper. These targets include a 60\% reduction in greenhouse gas emissions from transport by 2050 compared to 1990 levels. Other targets are a $20 \%$ intermediate target reduction 
by 2030 compared to 2008 levels and 20\% economy-wide reduction by 2020 compared to 1990 levels. However, based on EEA estimates, the share of road transport contribution out of Europe's total carbon dioxide emissions increased in 2018 to $26.3 \%$, which is $27.3 \%$ above 1990 levels. This recent increase in $\mathrm{CO}_{2}$ emissions was mainly driven by higher oil consumption from vehicle transport. The per-car average $\mathrm{CO}_{2}$ emissions of new cars sold in the EU increased for the first time since monitoring started under current EU legislation in 2010. It makes achieving the EU's 2020 target for emission reductions, and, to an even greater degree, the target set for 2030, increasingly uncertain [6,7]. Furthermore, carbon emissions of road transportation accounted for $82 \%$ of the EU's total greenhouse gas emissions, making the road transport sector the largest contributor of EU greenhouse gas emissions.

Recently, new carbon dioxide emissions standards for cars and vans set in Regulation EU 2019/631 were adopted by the European Parliament and the Council of Ministers and applied starting 1 January 2020 as a condition for vehicle manufacturers to comply with, to support the previously mentioned reduction targets. However, new policies and measures need to be urgently considered in EU Member States to decrease transport emissions and meet long-term and intermediate goals. Therefore, it is nowadays of great significance to study the effectiveness of European transport policies and measures supporting the greenhouse gas emission from transport reduction targets, and any related insight is highly policy-relevant. As the automotive sector is the backbone of European industry, providing jobs to 14.6 million Europeans in 2018 [8], it is essential to seek an efficient policy framework, both for the sector's competitiveness and road transport emission reduction perspectives. Particularly, European Automobile Manufacturers Association (ACEA) calls for assessing various measures to determine their emission reduction potential, such as carbon dioxide taxation [5].

Beginning with [9] suggesting polluting goods might be taxed, various papers have attempted to examine the impact of taxes on new car purchases and $\mathrm{CO}_{2}$ emissions (e.g., [10-15]). However, only a few studies incorporate taxes explicitly within econometric models (e.g., [16]). There is minimal evidence on the effectiveness and impact of carbon taxes in the European and North American contexts $[17,18]$, even though carbon taxes have been imposed in various countries in these regions. Although increasing attention has been paid to new car sales by examining the impact of fiscal policy tools such as taxes, the majority of current research focuses on a single country, and associated effects are mixed.

This topic is important to investigate given the importance of the European automotive sector and the absence of cross-country evidence addressing the influence of imposed or changed carbon tax levels on the composition of the EU passenger car fleet. We seek to fill the gap in the research of whether implementing or changing the carbon tax level may help to interpret variations in car purchasers' behavior to favor more environmentally friendly types of passenger cars. The impetus for this research stems from calls in prior literature for additional studies determining the car fleet emissions reduction potential of carbon taxes $[16,17,19]$. This paper aims to fill this research gap and makes several contributions to the research on the impact of fiscal measures on the varying composition of passenger car sales and new car fleet $\mathrm{CO}_{2}$ emission intensities. First, we observe changes in consumers' preferences for the type of motor energy associated with variations in carbon tax levels by employing cross-country and longitudinal analysis. The sample consists of 17 countries in the European region covering the years 2013-2017. Second, to the best of our knowledge, we explore the associations on the most extensive dataset used in this research to date at the European level.

Consistent with [16], consumers' preferences are measured using the ratio of petrol fuel vehicles to total new car registrations, diesel fuel vehicles to total new car registrations, and alternative fuel vehicles to total new car registrations. According to [16], these ratios may be the key to determining the effectiveness of European policies aiming to reduce greenhouse gas emissions from transport and meet the related reduction targets. Finally, based on the consistent estimation of the causal effect of carbon taxes, controlling for price and socioeconomic factors, this paper provides the first empirical evidence of the identified switching pattern in the proportion of new passenger car purchases. This switching pattern from less efficient and more carbon-producing petrol fuel cars to more efficient and less 
carbon-producing diesel fuel vehicles across the mentioned country-sample was found to be associated with the implemented new or increased existing carbon tax, making diesel fuel vehicles more attractive for new car purchasers. Furthermore, we observed significant effects of vehicle prices, fuel prices, interest rates, income, and vehicle stock on varying new car fleet structure. Our results have theoretical and practical implications for academics and policymakers to benefit from our research.

Theoretically, carbon-emitting practices research might usefully include carbon taxes to draw conclusions about new passenger car fleet emission intensities, controlling for price and socioeconomic factors. In practical terms, our observed shift from petrol to diesel vehicles was described by $[16,20]$ as a potentially important indicator for passenger car carbon dioxide emissions. This shift serves as a proxy for the reduced carbon dioxide emissions intensity of the passenger car fleet, sending a positive message to policymakers attempting to reduce greenhouse gas emissions from transport.

The next section presents a related literature review. The data and methodology for the empirical tests are described in Section 2. A summary of the results is in Section 4, followed by concluding remarks in Section 5.

\section{Literature Review}

Governments impose taxes as an important policy tool to discourage a range of unfavorable behaviors [21]. In the case of passenger cars, environmental taxes are used to increase the social cost of externalities such as carbon dioxide emissions, local air pollution, traffic congestion, and traffic accidents [17,22]. Vehicle taxes are considered necessary fiscal and policy instruments [10], encouraging changes in motorists' purchasing patterns generally in favor of less carbon-emitting vehicles by increasing prices of carbon-intensive vehicles and firms' production processes to reduce emissions per unit $[2,16]$. While vehicle taxes are not harmonized, most EU countries impose a range of taxes on automobiles $[16,23]$.

The European Commission has not yet announced the success of supply-side policy instruments (such as passenger car VA) as hoped to reduce carbon dioxide emissions. Therefore, the impact of demand-side fiscal measures on car fleet carbon dioxide emissions intensity has become the focus of related studies [16]. According to the research of [24], a carbon tax is seen from the climate change perspective as a suitable demand-side fiscal measure, making gasoline more expensive and incentivizing the switch to vehicles that run on alternative fuels such as electric vehicles.

The concept of the social cost of carbon was first discussed in the 1980s. Since then, several countries have introduced a carbon tax on vehicle fuel to influence consumers' choices in favor of more environmentally friendly types of passenger cars. A fiscal goal is to raise money to fund government operations, including road building and maintenance. A policy goal of these taxes is to decrease carbon dioxide $\left(\mathrm{CO}_{2}\right)$ emissions and transform today's world into a low-carbon-use economy [25]. Carbon taxes differ from other consumption taxes, as they are explicitly designed to reduce environmental externalities and impose a disincentive on fossil fuel consumption [17]. Prior literature suggests that carbon taxes are an effective measure to curb carbon dioxide, but due to the hot-button nature of taxes, they are seldom mentioned by politicians [21,26].

Beginning with [9] pointing out that polluting goods should be taxed, research on the fiscal drivers of the varying composition of new passenger car sales and car fleet carbon dioxide emissions intensity has been primarily conducted as single-country studies (e.g., [12-15,20,27-35]). Giblin and McNabola [30] pointed out that despite the annual tax revenue shortfall in direct income, introducing new carbon-based taxes is associated with a carbon dioxide emissions intensity reduction due to a shift to smaller vehicles and vehicles that run on diesel in Ireland. This finding was later supported by the study of [13] who observed a similar purchasing pattern of a substantial shift from petrol to diesel cars in Ireland, as the effect of car owners' attempts to shift to the lower tax rates.

Motivated by diesel being less carbon-dioxide-polluting than gasoline on average, Broadstock and Chen [20] sought policy instruments that encourage substitution between gasoline and diesel that are available to policymakers to reduce the emission-based externalities from road transport in the UK. 
They showed that price factors could affect emissions. However, tax rates were not explicitly used in the model. Kok [14] examined the phenomenon in The Netherlands, which has the most salient $\mathrm{CO}_{2}$-based fiscal scheme among the EU Member States, and found $\mathrm{CO}_{2}$-based taxes for company cars seem to significantly contribute to an observed turnaround in purchasing behavior toward low-carbon cars. Recently, Yang and Tang [36] provided evidence that tax incentives promote and improve fleet fuel efficiency in China. Kverndokk et al. [33] studied various policy instruments influencing the stock of polluting cars in Norway. They found that taxing polluting cars makes emission-free cars relatively more attractive.

Contrary evidence is provided by [12] who found that a carbon tax has small effects on the average fuel consumption and $\mathrm{CO}_{2}$ intensity of new cars in France. Givord et al. [12], meanwhile, argue that the $\mathrm{CO}_{2}$ emissions tax does not fulfill its primary objective of influencing consumers' behavior to prefer the purchase of more environmentally friendly passenger vehicles in Africa. Instead, they found that factor price was the most important criterion to influence consumers' purchasing decisions, and "green thinking" was the least important consideration for consumers. Similarly, de Villers and Nienaber [35] pointed out that fiscal tax policy to penalize polluting cars in Africa did not result in an intended shift to more fuel-efficient cars [27].

Despite these national studies, little theoretical and empirical work asks how fiscal and other measures affect new passenger car sales and carbon dioxide emission intensities [16]. Ryan, et al. [16] attempt to explain changing passenger car sales and carbon dioxide emission intensities by fiscal and other relevant socioeconomic variables, using the EU15 country-sample over the period 1995-2004. They contribute to the literature by providing evidence that taxes on cars affect total vehicle sales, the share of petrol and diesel fuel vehicle sales, and $\mathrm{CO}_{2}$ emission intensities in the $\mathrm{EU}$, in particular, by finding that supply-side fiscal measures (European VA) have a weaker impact than the demand-side fiscal measures (vehicle and fuel taxes) on car fleet carbon dioxide emissions reductions. Furthermore, their results show that fuel price, income, and vehicle and fuel taxes have a significant effect on consumer vehicle purchasing behavior affecting new passenger car sales. Similarly, Gerlagh et al. [29] attempted to examine the effect of national fiscal policies on decarbonization of the new car fleet in EU15 over the period 2001-2010, and [31] in seven European countries over the period 1998-2011. They suggest that the increase in the fuel tax leads to an increase in the share of more fuel-efficient diesel cars. Klier and Linn [32] add that carbon dioxide taxes reduced new vehicle registrations over the period 2005-2010, particularly in Germany, Sweden, and France. Further, prior studies have determined that various socioeconomic factors such as the price of cars, fuel price, income level, population density, and vehicle stock are significantly associated with varying car purchasers' behavior (see, e.g., $[16,28,34])$.

\section{Hypotheses}

Imposing or increasing carbon taxes likely causes some car purchasers to buy or switch to a more efficient and less carbon-producing type of vehicle. Considering the review of related studies, we hypothesize that shifts in newly purchased petrol/diesel/alternative fuel passenger cars are associated with carbon tax levels. Empirically, these hypotheses imply that:

Hypothesis 1. Changes in carbon tax rates will be negatively related to changes in the proportion of new petrol fuel vehicles registered.

Hypothesis 2. Changes in carbon tax rates will be positively related to changes in the proportion of new diesel fuel vehicles registered.

Hypothesis 3. Changes in carbon tax rates will be positively related to changes in the proportion of new alternatives fuel vehicles registered. 


\section{Data and Methodology}

The empirical tests examine whether carbon taxes affect new car purchases in 17 Organisation for Economic Co-operation and Development (OECD) countries from 2013 to 2017, the period when the required data are available for both the dependent and independent variables. Passenger cars (vehicles, cars, automobiles, autos) are defined as per [37], "Road motor vehicle, other than a moped or a motor cycle intended for the carriage of passengers and designed to seat no more than nine persons (including the driver)." Control variables for the model were selected following [16]. Data were compiled from publicly available country-level sources, as shown in Appendix A. A description of the data used to calculate the variables included in the empirical models can also be found in Appendix A.

Panel data models are set in the form of static and dynamic models [38]. It is not appropriate to estimate the dynamic models using Ordinary Least Squares (OLS), Fixed Effects (FE), or Random Effects (RE), as they are considered static panel models. It should be noted that the presence of a lagged dependent variable causes an endogeneity issue. To answer the estimation problems associated with the static panel models, we used the two-step system Generalized Method of Moments (GMM) dynamic panel data estimator, developed by $[39,40]$, to examine the association between carbon taxes and the composition of new car purchases. Implementation of the two-step system GMM estimator addresses endogeneity bias, as the dependent variable can be correlated with the lag of the dependent variable, or there could be reverse causality. This estimator has been used in numerous recent environmental studies [38,41-43]. Moreover, the GMM estimator is applied for small $\mathrm{T}$ and large $\mathrm{N}$ panels, as we have a dataset with many countries and few years. On the other hand, we followed the suggestions made by [44] due to difficulties in choosing appropriate contemporaneous instruments, where the dependent variable was instrumented with 2 lags. We used the two-step system GMM dynamic panel data estimator with [45] finite-sample correction (the advanced version of this estimator in STATA version 13, the 'xtandond2' routine, developed by [44], was employed). As our panel data have missing values, the data were transformed using orthogonal deviations, allowing us to characterize valid instruments. After estimating the system GMM model, tests for the overidentifying restrictions and the serial correlations of the residuals were employed using the Hansen J and autoregressive AR (2) tests, respectively. Low Hansen J-test [46] and AR (2) test results (with high $p$-values) show that there is no potential endogeneity and the differenced errors are not serially autocorrelated, respectively. In addition, the Wald $\chi^{2}$ test helps us to observe the overall model fit.

$$
N C P_{i t}=\alpha N C P_{i t-1}+\beta_{1} C T_{i t}+\beta_{2} X_{i t}+\mu_{t}+\varepsilon_{i t}
$$

where $N C P_{i t}$ is the composition of new car purchases in country $i$ at time $t, C T$ represents carbon taxes, $\alpha, \beta_{1}$, and $\beta_{2}$ are coefficients to be estimated, and $X_{i t}$ is a vector of control variables. $\mu_{t}$ is the country-specific effect, and $\varepsilon_{i t}$ is the error term, both following the independent and identically distributed (i.i.d.) processes. The expression $\mathrm{NCP}_{t-1}$ on the right-hand side of the equation is treated as endogenous and shows a lagged value of the dependent variable, NCP. One of the advantages of this estimator is that it allows us to eliminate unobserved country-specific effects by taking the first differences of Equation (1), resulting in Equation (2).

$$
N C P_{i t}-N C P_{i t-1}=\alpha\left(N C P_{i t-1}-N C P_{i t-2}\right)+\beta_{1}\left(C T_{i t}-C T_{i t-1}\right)+\beta_{2}\left(X_{i t}-X_{i t-1}\right)^{\prime}+\left(\varepsilon_{i t}-\varepsilon_{i t-1}\right)
$$

The dependent variable (NCP) was calculated similarly to [16], but with three versions of the dependent variable: PetrolShare- the proportion of petrol fuel vehicles in new car purchases $\left(N_{C} P_{P S}\right)$; DieselShare - the proportion of diesel fuel vehicles in new car purchases $\left(N C P_{D S}\right)$, and AltShare-the proportion of alternative fuel vehicles in new car purchases $\left(N C P_{A S}\right)$. The primary independent variable $(C T)$ is the average effective carbon tax rate applied as the average fuel excise tax on energy-related $\mathrm{CO}_{2}$ emissions from road transport, in Euro per ton of $\mathrm{CO}_{2}$. As the fuel and carbon taxes are considered the only policy instruments that can successfully set a price on carbon [47], we used average effective 
carbon tax rates instead of the explicit carbon tax rate. As noted in [47] (p. 2), "The effective carbon tax is the sum of fuel excise taxes ... and explicit carbon taxes ... " Additionally, while the explicit carbon tax rate plays a significant role in the non-road sector, the average effective carbon tax rate on road emissions is the main interest of our study as road transport has stronger carbon price signals due to high fuel taxes [47].

The control variables shown in Equation (1), $X_{i t}$, are as follows: Vehicle stock (VS), vehicle price $(V P)$, income $(I N C)$, population density $(P D)$, petrol fuel price $(P F P)$, diesel fuel price $(D F P)$, and average fuel price $(A F P)$. Vehicle stock refers to the total number of passenger cars in the country, based on per thousand inhabitants. The vehicle stock measure is taken from [48]. Vehicle price is the average passenger car price, including tax (in Euros). The vehicle price measure is taken from [49]. Income corresponds to the gross national income (GNI) per capita, based on constant 2010 US \$ converted to Euros, according to the official exchange rate in 2010. The income measure is taken from [50]. Population density refers to the number of people per square kilometer for each country, and is estimated as the midyear population divided by land area in square kilometers. The population density measure is taken from [51]. Inflation corresponds to the consumer price index, which is measured by the annual percentage change in the cost over time to the average consumer of gaining a basket of goods and services that consumers pay for. The inflation measure is taken from [52]. Interest rate refers to long-term interest rates of government bonds maturing in ten years as measured as the average of daily rates. The interest rate measure is taken from [53]. Petrol, diesel, and sales-weighted average fuel prices are included in the models, including duties and taxes, which refers to the most frequently charged fuel price. Petrol, diesel, and sales-weighted average fuel prices measures are taken from [54,55]. The final sample consists of 17 OECD countries (Austria, Belgium, Estonia, Finland, France, Germany, Hungary, Ireland, Netherlands, Norway, Poland, Slovenia, Spain, Sweden, Switzerland, Turkey, United Kingdom) over the period 2013-2017. The summary statistics and correlation matrix of the variables used in the analysis are shown in Table 1. 
Table 1. Descriptive statistics and correlation matrix.

\begin{tabular}{|c|c|c|c|c|c|c|c|c|c|c|c|c|c|c|c|c|c|c|}
\hline Variable & Obs. & Mean & S.D. & Min. & Max. & $N C P_{P S}$ & $N C P_{D S}$ & $N C P_{A S}$ & $C T$ & $V C$ & $V P$ & $I N C$ & $P F P$ & $D F P$ & $A P$ & $P D$ & INF & INT \\
\hline PetrolShare & 93 & 0.48 & 0.13 & 0.25 & 0.80 & $1.00 *$ & & & & & & & & & & & & \\
\hline DieselShare & 93 & 0.50 & 0.13 & 0.17 & 0.74 & $-0.95 *$ & $1.00 *$ & & & & & & & & & & & \\
\hline AltShare & 93 & 0.03 & 0.04 & 0.00 & 0.25 & -0.15 & -0.18 & $1.00 *$ & & & & & & & & & & \\
\hline CarbonTax & 89 & 153.88 & 65.80 & 19.55 & 318.39 & $0.25 *$ & -0.26 * & 0.06 & $1.00 *$ & & & & & & & & & \\
\hline VehicleStock (in thousands) & 110 & $11,309.66$ & $13,293.06$ & 634.60 & $45,800.00$ & 0.00 & 0.00 & 0.02 & 0.10 & 1.00 * & & & & & & & & \\
\hline VehiclePrice & 110 & 27.47 & 5.88 & 19.35 & 47.28 & 0.18 & $-0.30 *$ & $0.36^{*}$ & $0.46^{*}$ & -0.09 & $1.00 *$ & & & & & & & \\
\hline Income & 110 & 33.43 & 18.89 & 9.25 & 89.27 & 0.17 & $-0.26^{*}$ & $0.25 *$ & $0.46^{*}$ & -0.04 & $0.90 *$ & $1.00 *$ & & & & & & \\
\hline PFuelPrice & 110 & 1429.15 & 108.28 & 1290.78 & 1573.24 & $-0.21 *$ & $0.24 *$ & -0.09 & $-0.75 *$ & -0.02 & -0.19 & -0.18 & $1.00 *$ & & & & & \\
\hline DFuelPrice & 110 & 1282.75 & 121.17 & 1123.29 & 1445.59 & -0.20 & $0.22 *$ & -0.07 & $-0.75^{*}$ & -0.02 & -0.18 & -0.18 & $1.00 *$ & $1.00 *$ & & & & \\
\hline AvgPrice & 98 & 1350.78 & 111.38 & 1167.73 & 1541.11 & -0.03 & 0.06 & -0.08 & $-0.71 *$ & -0.03 & -0.13 & -0.12 & $0.98 *$ & $0.98 *$ & 1.00 * & & & \\
\hline PopDensity & 110 & 137.82 & 119.42 & 13.91 & 508.50 & $0.37^{*}$ & $-0.32 *$ & -0.15 & 0.19 & $0.32 *$ & 0.01 & 0.17 & -0.01 & -0.01 & 0.05 & $1.00 *$ & & \\
\hline Inflation & 110 & 1.17 & 1.92 & -1.14 & 11.14 & -0.11 & 0.08 & 0.10 & -0.04 & -0.02 & -0.05 & -0.17 & 0.01 & 0.03 & 0.00 & -0.03 & $1.00 *$ & \\
\hline Interest rate & 110 & 2.22 & 2.22 & -0.36 & 11.43 & $-0.30 *$ & $0.27^{*}$ & 0.09 & $-0.31 *$ & -0.03 & -0.40 * & $-0.53 *$ & $0.31 *$ & 0.31 * & 0.23 * & -0.16 & 0.68 * & 1.00 * \\
\hline
\end{tabular}

${ }^{*}$ Correlation is significant at the 0.05 level. 


\section{Results}

In all three models, the dependent and independent variables were transformed using natural logs before the GMM estimation. Interpreting the models requires consideration of the elasticity of the dependent variables with respect to the independent variables. The coefficients represent the percentage change in the dependent variable due to a $1 \%$ change in the independent variables. The results of the empirical tests are shown in Table 2.

Table 2. System generalized method-of-moments (GMM; Arellano-Bond) estimates.

\begin{tabular}{|c|c|c|c|}
\hline & $\begin{array}{c}\text { Model 1 } \\
\text { (PetrolShare) }\end{array}$ & $\begin{array}{c}\text { Model } 2 \\
\text { (DieselShare) }\end{array}$ & $\begin{array}{c}\text { Model } 3 \\
\text { (AltShare) }\end{array}$ \\
\hline CarbonTax & $\begin{array}{c}-0.321^{* *} \\
(0.003)\end{array}$ & $\begin{array}{l}0.264 \text { * } \\
(0.025)\end{array}$ & $\begin{array}{l}-1.499 \\
(0.128)\end{array}$ \\
\hline VehiclePrice & $\begin{array}{c}-0.656^{* *} \\
(0.002)\end{array}$ & $\begin{array}{c}-0.0457 \\
(0.924)\end{array}$ & $\begin{array}{c}4.459 \\
(0.050)\end{array}$ \\
\hline Income & $\begin{array}{l}0.345^{* *} \\
(0.002)\end{array}$ & $\begin{array}{c}-0.0504 \\
(0.764)\end{array}$ & $\begin{array}{l}-0.523 \\
(0.514)\end{array}$ \\
\hline PFuelPrice & $\begin{array}{c}-1.450 * \\
(0.019)\end{array}$ & & \\
\hline DFuelPrice & & $\begin{array}{l}1.012^{* * *} \\
(0.000)\end{array}$ & \\
\hline AvgFuelPrice & & & $\begin{array}{c}0.876 \\
(0.738)\end{array}$ \\
\hline PopDensity & $\begin{array}{l}-0.043 \\
(0.149)\end{array}$ & $\begin{array}{l}0.0121 \\
(0.767)\end{array}$ & $\begin{array}{l}0.0643 \\
(0.806)\end{array}$ \\
\hline VehicleStock & $\begin{array}{l}0.048^{* *} \\
(0.009)\end{array}$ & $\begin{array}{c}-0.00522 \\
(0.873)\end{array}$ & $\begin{array}{l}0.0218 \\
(0.913)\end{array}$ \\
\hline Inflation & $\begin{array}{c}0.001 \\
(0.916)\end{array}$ & $\begin{array}{c}-0.0138 \\
(0.305)\end{array}$ & $\begin{array}{l}-0.108 \\
(0.288)\end{array}$ \\
\hline Interest rate & $\begin{array}{l}0.097^{*} \\
(0.029)\end{array}$ & $\begin{array}{c}-0.00840 \\
(0.835)\end{array}$ & $\begin{array}{c}0.203 \\
(0.509)\end{array}$ \\
\hline LagPetrolShare & $\begin{array}{c}1.423 * * * \\
(0.000)\end{array}$ & & \\
\hline LagDieselShare & & $\begin{array}{l}1.194^{* * *} \\
(0.000)\end{array}$ & \\
\hline LagAltShare & & & $\begin{array}{c}0.459 \\
(0.174)\end{array}$ \\
\hline Observations & 47 & 47 & 47 \\
\hline Number of Countries & 17 & 17 & 17 \\
\hline $\begin{array}{l}\text { Number of } \\
\text { Instruments }\end{array}$ & 16 & 16 & 16 \\
\hline Wald $\chi 2$ & $7868.0^{* * *}$ & $86,804.3^{* * *}$ & 332.4 \\
\hline $\operatorname{AR}(1)$ & 0.177 & 0.0824 & 0.265 \\
\hline $\operatorname{AR}(2)$ & 0.545 & 0.266 & 0.224 \\
\hline Hansen J-test & 1.55 & 13.00 & 10.74 \\
\hline Hansen ( $p$-value) & 0.907 & 0.023 & 0.057 \\
\hline
\end{tabular}

The Wald $\chi^{2}$ test for the overall model holds in Models $1-2(p<0.05)$. The Arellano-Bond test for $\mathrm{AR}(2)$ in Models 1-2 suggest that serial correlation is not a concern ( $p$-values ranging from 0.224 to 0.545). The Hansen J-test of over-identification of the system GMM instruments in Models 1 does not reject the null that the instruments are uncorrelated with the error term $(p=0.907)$, confirming the validity of the instruments used in the system GMM estimation. The number of instruments does not exceed the number of countries (i.e., $16<17$ ). All specifications contain a constant, lagged dependent variable $_{(t-1)}$, and year dummies (not shown). All variables are in logs. Windmeijer-corrected standard errors are in parentheses. 
In Model 1, where the dependent variable is the proportion of petrol fuel cars in new car registrations, carbon taxes have a negative and significant effect. A $1 \%$ increase in carbon taxes caused a $0.321 \%$ decrease in the proportion of petrol vehicles. In Model 2, where the dependent variable is the proportion of diesel fuel cars in new car registrations, carbon taxes have a positive and significant effect. A $1 \%$ increase in carbon taxes caused a $0.264 \%$ increase in the proportion of diesel vehicles. We can conclude that carbon taxes influence consumer behavior, causing switching from petrol fuel to diesel fuel vehicles. Two characteristics of diesel fuel vehicles can explain this finding. They are more efficient, using less fuel per kilometer driven [56,57], and diesel cars produce fewer carbon emissions per kilometer driven $[16,56,57]$. In 2017, the carbon emissions from diesel vehicles were $13 \%$ less than petrol vehicles when driven the same distance, according to [14]. As carbon taxes increase, this makes diesel cars more attractive.

Increases in average passenger car vehicle prices caused a significant decrease in the proportion of petrol fuel vehicles. A $1 \%$ increase in average vehicle price caused the proportion of petrol cars to decrease by $0.656 \%$. This substitution of alternative fuel vehicles for petrol vehicles could be due to a narrowing difference in price between alternative fuel vehicles and other vehicles [58]. When the prices of petrol fuel vehicles increase, alternative fuel vehicles become more attractive for some buyers, particularly considering the total cost of ownership.

Income is positively related to the proportion of petrol cars purchased. As income increases, the cost of operating a vehicle becomes a smaller percentage of disposable income. If fuel price becomes a less important criterion in the vehicle purchase decision, other characteristics such as vehicle range and the availability of fueling stations might become more important to car buyers. These are two areas where petrol cars still have a significant advantage over many alternative fuel vehicles.

The price of petrol fuel is negatively related to the proportion of petrol fuel vehicles purchased. A $1 \%$ increase in the price of petrol fuel caused a $1.450 \%$ decrease in the proportion of petrol vehicles. As fuel prices are a significant portion of the total cost of ownership [59], increasing prices cause a shift to more efficient vehicles and those that operate on less costly fuel, such as diesel and alternative fuel vehicles.

The price of diesel fuel is positively related to the proportion of diesel fuel vehicles purchased. A $1 \%$ increase in the price of diesel fuel caused a 1.012\% increase in the proportion of diesel vehicles. The correlation between petrol and diesel fuel prices is greater than $0.99(p<0.001)$. On average, when petrol fuel prices increase, diesel fuel prices also increase. Therefore, increasing fuel prices make diesel vehicles more attractive, due to their relative efficiency. Fuel price, however, was not significantly related to the proportion of alternative fuel vehicles purchased.

Vehicle stock was positively related to the proportion of petrol vehicles purchased, which suggests that in larger and better-developed markets, petrol vehicles maintained their popularity in the sample period. Interest rates were likewise positively related to the proportion of petrol vehicles purchased. Increased interest rates increase the cost of purchasing vehicles partially or wholly financed. When the prices of all vehicles increase similarly, petrol fuel vehicles might be more attractive due to their average lower cost [59]. None of the other variables included in the models were significant except for the lagged versions of the dependent variables.

In additional untabulated results (results were submitted to the reviewers and are available from the authors), the empirical tests were performed on countries in the sample that are members of the EU Emissions Trading System (EU ETS). The results are substantively equivalent for the main variables of interest, carbon tax rates. In addition, they are similar for fuel prices.

\section{Concluding Remarks}

Taxes are a powerful tool in the policymaker's toolbox. Behavior can be influenced by new taxes, or by small changes in existing tax rates. Small changes in behavior across an entire population can lead to large-scale change. One suggestion for reducing carbon emissions is implementing new carbon taxes and increasing existing carbon taxes. Research on the determinants of car purchases has mainly 
revolved around the various socioeconomic factors while ignoring the role of carbon taxes at the cross-country level. Building on prior studies at the single country level, we hypothesize that carbon taxes are negatively associated with a shift in petrol car purchases, and positively associated with a shift to diesel and alternative fuel vehicles. Using country-level data across 17 countries from 2013 to 2017, we find strong support for a negative association between carbon taxes and new petrol car registrations, and a positive association between carbon taxes and a shift to diesel cars. Therefore, the findings provide support for Hypothesis 1 and Hypothesis 2. The findings do not support Hypothesis 3. Our findings show that these changes in tax rates influence consumer behavior, causing buyers to switch from petrol fuel vehicles to more efficient and less carbon-producing diesel fuel vehicles. On the other hand, it is argued by [60] that replacing gasoline cars by diesel cars reduces carbon emissions at a higher social cost, because diesel cars produce more conventional pollution such as a higher emission of particulates, even though they generate fewer greenhouse gases. Therefore, diesel fuel vehicles are often recognized as an outdated technology [61], and have started to be banned in countries like France, Belgium, and Germany [62]. However, "Pro-diesel protesters" in Germany recently protested against forthcoming diesel driving bans [62]. Our findings can partly explain the reason behind the protest in those countries. Regulators can use these results as support for the efficacy of carbon taxes.

The relevant control variables were added based on previous research on country-level car registrations. Further research could include psychological variables in the model, which might help explain shifts in car purchasing behavior related to less or more efficient and carbon-emitting vehicles in the European region. One limitation of the current study is that there might be other unaccounted for psychological variables that could influence car purchasing behavior. More specifically, car purchasing behavior seems to depend on many unobservable factors such as an inner feeling of obligation (personal norm) and symbolic motives (expressed as the social status through cars), which stems from social psychology and economic psychology disciplinary fields [63]. However, if the aforementioned variables are stable through time, it can be considered that they are mainly captured by the fixed effects. Therefore, future studies should take into consideration the impact of other relevant variables that change across countries and over years that are not captured in our model.

Another limitation of the papers stems from possible reverse causality and endogeneity. In practice, implementation of carbon taxes can be adjusted based on the number of car registrations. In addition, consumers' car purchasing behaviors, and, subsequently, the design of the tax law related to carbon emissions, may change. The direction and dynamic nature of the relationship between carbon taxes and car purchasing behavior must be identified. Although most reverse causality and endogeneity issues were ruled out by employing the GMM estimator, they were not fully ruled out, due to the lack of data. Future research on car purchases can explore alternative measures of carbon taxes at the cross-cross country level.

Future research might also deal with the problem of negative externalities from the manufacturing of more resource-intensive electric vehicles that were recently shown to be higher than for gasoline-powered vehicles $[64,65]$. The higher resource-intensiveness of electric vehicles mainly stems from used materials such as copper, aluminum, lithium, and others to build batteries. Finally, we encourage researchers to also determine the ability of electric cars to reduce the gasoline consumption, to judge the prospect of electric cars as a relevant climate change solution [24].

Author Contributions: Conceptualization, O.N.; Methodology, O.N.; Software, O.N.; Validation, B.D.; Formal Analysis, O.N., B.D.; Investigation, O.N., J.V., B.D.; Resources, O.N., J.V., B.D.; Data Curation, O.N., J.V.; Writing-Original Draft Preparation, O.N., J.V., B.D.; Writing-Review \& Editing, O.N., J.V., B.D.; Visualization, O.N.; Supervision, B.D.; Project Administration, O.N., B.D.; Funding Acquisition, J.V. All authors have read and agreed to the published version of the manuscript.

Funding: This work was supported by the Grant Agency Academia aurea (GA AA) under Grant number GA/16/2019: Future of the Automotive Industry: The Effect of Institutional Settings on the Car Sales and the Consumer Behaviour for Purchasing Cars; and by the Internal Grant Agency of the Tomas Bata University in Zlín under Grant No. IGA/FaME/2020/001. 
Acknowledgments: We would like to thank Lisa Ryan for her thoughtful assistance in preparing the data for analysis.

Conflicts of Interest: The authors declare no conflicts of interest, financial or non-financial, in conducting this research and writing this article.

Data Availability: All data are publicly available from the sources cited. 


\section{Appendix A. Data Description and Sources}

\begin{tabular}{|c|c|c|c|}
\hline Variable & Description & Source/Formula & URL \\
\hline Petrol Registrations & $\mathrm{P}=\mathrm{Number}$ of new car registrations where fuel type is petrol & Ref. [66] & $\begin{array}{l}\text { https://appsso.eurostat.ec.europa.eu/nui/submi } \\
\text { tViewTableAction.do }\end{array}$ \\
\hline Diesel Registrations & $D=$ Number of new car registrations where fuel type is diesel & Ref. [66] & $\begin{array}{l}\text { https://appsso.eurostat.ec.europa.eu/nui/submi } \\
\text { tViewTableAction.do }\end{array}$ \\
\hline Alternative Fuel Registrations & $A=$ Number of new car registrations where fuel type is other & Ref. [66] & $\begin{array}{l}\text { https://appsso.eurostat.ec.europa.eu/nui/submi } \\
\text { tViewTableAction.do }\end{array}$ \\
\hline PetrolShare & Proportion of new car registrations where fuel type is petrol & $\mathrm{P} /(\mathrm{P}+\mathrm{D}+\mathrm{A})$ & \\
\hline DieselShare & Proportion of new car registrations where fuel type is diesel & $\mathrm{D} /(\mathrm{P}+\mathrm{D}+\mathrm{A})$ & \\
\hline AltShare & Proportion of new car registrations where fuel type is other & $\mathrm{A} /(\mathrm{P}+\mathrm{D}+\mathrm{A})$ & \\
\hline CarbonTax & Average effective carbon tax rate (Euros per ton of $\mathrm{CO}_{2}$ ) & Refs. $[67,68]$ & $\begin{array}{l}\text { https://doi.org/10.1787/888934009121; } \\
\text { https://www.oecd-ilibrary.org/taxation/taxing- } \\
\text { energy-use_9789264183933-en }\end{array}$ \\
\hline VehicleStock & Total stock of passenger cars & Ref. [48] & $\begin{array}{l}\text { https://appsso.eurostat.ec.europa.eu/nui/show. } \\
\text { do?dataset=tran_r_vehst\&lang=en }\end{array}$ \\
\hline VehiclePrice & Average price (including tax) of passenger cars (in Euros) & Ref. [49] & http://eupocketbook.org/tables/ \\
\hline Income & GNI per capita in constant 2010 US $\$$ converted to Euros & Ref. [50] & $\begin{array}{l}\text { https://data.worldbank.org/indicator/NY.GDP. } \\
\text { PCAP.KD }\end{array}$ \\
\hline Inflation & Inflation as measured by the consumer price index & Ref. [50] & $\begin{array}{l}\text { https://data.worldbank.org/indicator/FP.CPI.TO } \\
\text { TL.ZG }\end{array}$ \\
\hline Interest rate & $\begin{array}{l}\text { Long-term interest rate measured as average daily interest rates } \\
\text { of government bonds maturing in ten years }\end{array}$ & Ref. [53] & https://doi.org/10.1787/662d712c-en \\
\hline PopDensity & Population density (per sq. km of land area) & Ref. [51] & $\begin{array}{l}\text { https: } \\
\text { //data.worldbank.org/indicator/EN.POP.DNST }\end{array}$ \\
\hline PFuelPrice & Petrol fuel price including taxes & Ref. [54] & $\begin{array}{l}\text { https: } \\
\text { //ec.europa.eu/energy/observatory/reports/ }\end{array}$ \\
\hline DFuelPrice & Diesel fuel price including taxes & Ref. [55] & $\begin{array}{l}\text { https://ec.europa.eu/energy/observatory/report } \\
\text { s/latest_prices_with_taxes.pdf }\end{array}$ \\
\hline AvgFuelPrice & Sales-weighted average fuel price & $($ PFuelPrice $\times$ PSales + DFuelPrice $\times$ DSales)/(PSales + DSales $)$ & \\
\hline
\end{tabular}




\section{References}

1. Grube, T.; Stolten, D. The Impact of Drive Cycles and Auxiliary Power on Passenger Car Fuel Economy. Energies 2018, 11, 1010. [CrossRef]

2. Santos, L.; Garaffa, R.; Lucena, A.F.P.; Szklo, A. Impacts of Carbon Pricing on Brazilian Industry: Domestic Vulnerability and International Trade Exposure. Sustainability 2018, 10, 2390. [CrossRef]

3. Martin, R.; Muuls, M.; Wagner, U.J. The Impact of the European Union Emissions Trading Scheme on Regulated Firms: What Is the Evidence after Ten Years? Rev. Environ. Econ. Policy 2016, 10, 129-148. [CrossRef]

4. Oestreich, A.M.; Tsiakas, I. Carbon Emissions and Stock Returns: Evidence from the EU Emissions Trading Scheme. J. Bank. Financ. 2015, 58, 294-308. [CrossRef]

5. ACEA (European Automobile Manufacturers Association). ACEA Position Paper. Reducing $\mathrm{CO}_{2}$ Emissions from Passenger Cars and Light Commercial Vehicles Post-2020. 2016. Available online: https://www.acea.be/uploads/publications/ACEA_Position_Paper_Reducing_CO2_Emissions_from_Passe nger_Cars_and_Light_Commercial_Vehicles_Post-2020.pdf (accessed on 17 August 2020).

6. EEA (European Environment Agency). Annual European Union Greenhouse Gas Inventory 1990-2017 and Inventory Report 2019. EEA Report No 6/2019; European Environment Agency: Copenhagen, Denmark, 2019.

7. EEA (European Environment Agency). Trends and Projections in Europe 2018. EEA Report No 16/2018; European Environment Agency: Copenhagen, Denmark, 2018.

8. ACEA (European Automobile Manufacturers Association). Employment in the EU Automotive Sector. 2020. Available online: https://www.acea.be/statistics/tag/category/employment-trends (accessed on 20 August 2020).

9. Yohe, G.W. Taxing consumption to finance reduced emissions. Econ. Lett. 1979, 2, 1-4. [CrossRef]

10. Eliasson, J.; Pyddoke, R.; Swärdh, J.E. Distributional effects of taxes on car fuel, use, ownership and purchases. Econ. Transp. 2018, 15, 1-15. [CrossRef]

11. Nienaber, G.; Barnard, B. The effect of passenger vehicle $\mathrm{CO}_{2}$ emissions tax on consumer behavior relating to new car purchase decisions. S. Afr. J. Account. Res. 2018, 32, 132-153. [CrossRef]

12. Givord, P.; Grislain-Letrémy, C.; Naegele, H. How do fuel taxes impact new car purchases? An evaluation using French consumer-level data. Energy Econ. 2018, 74, 76-96. [CrossRef]

13. Hennessy, H.; Tol, R.S.J. The impact of tax reform on new car purchases in Ireland. Energy Policy 2011, 39, 7059-7067. [CrossRef]

14. Kok, R. Six years of $\mathrm{CO}_{2}$-based tax incentives for new passenger cars in The Netherlands: Impacts on purchasing behavior trends and $\mathrm{CO}_{2}$ effectiveness. Transp. Res. Part A Policy Pract. 2015, 77, 137-153. [CrossRef]

15. Choisdealbha, A.N.; Timmons, S.; Lunn, P.D. Experimental evidence for the effects of emissions charges and efficiency information on consumer car choices. J. Clean. Prod. 2020, 254, 120140. [CrossRef]

16. Ryan, L.; Ferreira, S.; Convery, F. The impact of fiscal and other measures on new passenger car sales and $\mathrm{CO}_{2}$ emissions intensity: Evidence from Europe. Energy Econ. 2009, 31, 365-374. [CrossRef]

17. Rivers, N.; Schaufele, B. Salience of carbon taxes in the gasoline market. J. Environ. Econ. Manag. 2015, 74, 23-36. [CrossRef]

18. Verboven, F. The Effects of Environmental Policies in the Car Sector: Introduction. Econ. J. 2014, 124, F389-F392. [CrossRef]

19. Cerruti, D.; Alberini, A.; Linn, J. Charging Drivers by the Pound: How Does the UK Vehicle Tax System Affect CO2 Emissions? Environ. Resour. Econ. 2019, 74, 99-129. [CrossRef]

20. Broadstock, D.C.; Chen, X. A possible role for discriminatory fuel duty in reducing the emissions from road transport: Some UK evidence. Appl. Econ. Lett. 2013, 20, 540-544. [CrossRef]

21. Olivola, C.Y.; Sussman, A.B. Taxes and Consumer Behavior. In The Cambridge Handbook of Consumer Psychology; Norton, M.I., Rucker, D.D., Lamberton, C., Eds.; Cambridge University Press: Cambridge, UK, 2015; pp. 564-588. [CrossRef]

22. Li, S.; Linn, J.; Muehlegger, E. Gasoline Taxes and Consumer Behavior. Am. Econ. J. Econ. Policy 2014, 6, 302-342. [CrossRef] 
23. Runkel, M.; Mahler, A. A Comparison of $\mathrm{CO}_{2}$-Based Car Taxation in EU-28, Norway and Switzerland. Report for Transport \& Environment. 2018. Available online: https://www.transportenvironment.org/ (accessed on 20 May 2020).

24. Davis, L.W. How much are electric vehicles driven? Appl. Econ. Lett. 2019, 26, 1497-1502. [CrossRef]

25. Criqui, P.; Jaccard, M.; Sterner, T. Carbon Taxation: A Tale of Three Countries. Sustainability 2019, 11, 6280. [CrossRef]

26. Hardisty, D.J.; Johnson, E.J.; Weber, E.U. A Dirty Word or a Dirty World? Psychol. Sci. 2009, $21,86-92$. [CrossRef]

27. Alton, T.; Arndt, C.; Davies, R.; Hartley, F.; Makrelov, K.; Thurlow, J.; Ubogu, D. Introducing carbon taxes in South Africa. Appl. Energy 2014, 116, 344-354. [CrossRef]

28. Bates, J.M.; Pindyck, R.S. The Structure of World Energy Demand. Econ. J. 1980, 90, 664-665. [CrossRef]

29. Gerlagh, R.; van den Bijgaart, I.; Nijland, H.; Michielsen, T. Fiscal Policy and CO2 Emissions of New Passenger Cars in the EU. SSRN Electron. J. 2015, 69, 103-134. [CrossRef]

30. Giblin, S.; McNabola, A. Modelling the impacts of a carbon emission-differentiated vehicle tax system on $\mathrm{CO}_{2}$ emissions intensity from new vehicle purchases in Ireland. Energy Policy 2009, 37, 1404-1411. [CrossRef]

31. Grigolon, L.; Reynaert, M.; Verboven, F. Consumer Valuation of Fuel Costs and Tax Policy: Evidence from the European Car Market. Am. Econ. J. Econ. Policy 2018, 10, 193-225. [CrossRef]

32. Klier, T.; Linn, J. Using Taxes to Reduce Carbon Dioxide Emissions Rates of New Passenger Vehicles: Evidence from France, Germany, and Sweden. Am. Econ. J. Econ. Policy 2015, 7, 212-242. [CrossRef]

33. Kverndokk, S.; Figenbaum, E.; Hovi, J. Would my driving pattern change if my neighbor were to buy an emission-free car? Resour. Energy Econ. 2020, 60, 101153. [CrossRef]

34. Storchmann, K. Long-run gasoline demand for passenger cars: The role of income distribution. Energy Econ. 2005, 27, 25-58. [CrossRef]

35. de Villers, M.; Nienaber, S.G. The differential impact of $\mathrm{CO}_{2}$ penalties, $\mathrm{CO}_{2}$ incentives and information policies on consumer behaviour when purchasing a new motor vehicle. eJournal Tax Res. 2019, 17, 35-62.

36. Yang, Z.; Tang, M. Welfare Analysis of Government Subsidy Programs for Fuel-Efficient Vehicles and New Energy Vehicles in China. Environ. Resour. Econ. 2019, 74, 911-937. [CrossRef]

37. EC (European Commission). Glossary for Transport Statistics-European Commission. 2019. Available online: https://ec.europa.eu/eurostat/documents/3859598/10013293/KS-GQ-19-004-EN-N.pdf/b89 e58d3-72ca-49e0-a353-b4ea0dc8988f (accessed on 30 July 2020).

38. Kebede, S.G.; Heshmati, A. Energy Use and Labor Productivity in Ethiopia: The Case of the Manufacturing Industry. Energies 2020, 13, 2714. [CrossRef]

39. Arellano, M.; Bover, O. Another look at the instrumental variable estimation of error-components models. J. Econom. 1995, 68, 29-51. [CrossRef]

40. Blundell, R.; Bond, S. Initial conditions and moment restrictions in dynamic panel data models. J. Econom. 1998, 87, 115-143. [CrossRef]

41. Sung, B.; Song, W.Y. Does Dynamic Efficiency of Public Policy Promote Export Prformance? Evidence from Bioenergy Technology Sector. Energies 2017, 10, 2131. [CrossRef]

42. Sung, B.; Wen, C. Causal Dynamic Relationships between Political-Economic Factors and Export Performance in the Renewable Energy Technologies Market. Energies 2018, 11, 874. [CrossRef]

43. Westling, N.; Stromberg, P.M.; Swain, R.B. Can upstream ecosystems ensure safe drinking water-Insights from Sweden. Ecol. Econ. 2020, 169, 106552. [CrossRef]

44. Roodman, D. How to do xtabond2: An introduction to difference and system GMM in Stata. Stata J. 2009, 9, 86-136. [CrossRef]

45. Windmeijer, F. A finite sample correction for the variance of linear efficient two-step GMM estimators. J. Econom. 2005, 126, 25-51. [CrossRef]

46. Hansen, L.P. Large sample properties of generalized method of moments estimators. Econom. J. Econom. Soc. 1982, 50, 1029-1054. [CrossRef]

47. Taxing Energy Use (TEU). 2019. Available online: https://www.oecd.org/tax/tax-policy/brochure-taxing-ener gy-use-2019.pdf (accessed on 8 August 2020).

48. Eurostat 2019. Stock of Vehicles by Category and NUTS 2 Regions. Available online: https://appsso.eurostat. ec.europa.eu/nui/show.do?dataset=tran_r_vehst\&lang=en (accessed on 29 August 2019). 
49. International Council on Clean Transportation (ICCT). 2019/20 European Vehicle Market Statistics. 2019. Available online: http://eupocketbook.org/tables/ (accessed on 13 June 2020).

50. WDI 2019. GDP per Capita (Constant 2010 US\$). Available online: https://data.worldbank.org/indicator/NY. GDP.PCAP.KD (accessed on 29 August 2019).

51. WDI 2019. Population Density (People per sq. km of Land Area). Available online: https://data.worldbank.o $\mathrm{rg} /$ indicator/EN.POP.DNST (accessed on 29 August 2019).

52. WDI 2019. Inflation, Consumer Prices (Annual \%). Available online: https://data.worldbank.org/indicator/F P.CPI.TOTL.ZG (accessed on 25 August 2020).

53. OECD. Long-Term Interest Rates (Indicator). 2020. Available online: https://doi.org/10.1787/662d712c-en (accessed on 20 August 2020).

54. EU Oil Bulletin 2019a. Latest_Prices_with_Taxes.xlsx. Index of/Emos_Prod/Reports/Public. Available online: https://ec.europa.eu/energy/observatory/reports/ (accessed on 29 August 2019).

55. EU Oil Bulletin 2019b. Latest_Prices_with_Taxes.pdf. Index of/Emos_Prod/Reports/Public. Available online: https://ec.europa.eu/energy/observatory/reports/latest_prices_with_taxes.pdf (accessed on 29 August 2019).

56. Dornoff, J.; Rodríguez, F. Gasoline Versus Diesel Comparing $\mathrm{CO}_{2}$ Emission Levels of a Modern Medium Size Car Model under Laboratory and On-Road Testing Conditions. White Paper. May 2019. Available online: http s://theicct.org/sites/default/files/publications/Gas_v_Diesel_CO2_emissions_FV_20190503_1.pdf (accessed on 10 May 2020).

57. Rohini, A.; Prema, S. A review on thermal barrier coating for diesel engine and its characteristics studies. J. Phys. Conf. Ser. 2020, 1473, 012039. [CrossRef]

58. Palmer, K.; Tate, J.E.; Wadud, Z.; Nellthorp, J. Total cost of ownership and market share for hybrid and electric vehicles in the UK, US and Japan. Appl. Energy 2018, 209, 108-119. [CrossRef]

59. Belzowski, B.M.; Green, P. Total Cost of Ownership: A Gas Versus Diesel Comparison. Ann Arbor, MI: University of Michigan Transportation Research Institute. 2013. Available online: http://www.umtri.umich. edu/sites/default/files/UMTRI.TCO_.Final_.Report.06.24.13.Final_.pdf (accessed on 20 August 2020).

60. Mayeres, I.; Proost, S. The taxation of diesel cars in Belgium-revisited. Energy Policy 2013, 54, 33-41. [CrossRef]

61. Gross, M.; Sonnberger, M. How the diesel engine became a "dirty" actant: Compression ignitions and actor networks of blame. Energy Res. Soc. Sci. 2020, 61, 101359. [CrossRef]

62. Arning, K.; Ziefle, M. Defenders of Diesel: Anti-decarbonisation efforts and the pro-diesel protest movement in Germany. Energy Res. Soc. Sci. 2020, 63, 2-10. [CrossRef]

63. Peters, A.; de Haan, P.; Scholz, R.W. Understanding car-buying behavior: Psychological determinants of energy efficiency and practical implications. Int. J. Sustain. Transp. 2015, 9, 59-72. [CrossRef]

64. Michalek, J.J.; Chester, M.; Jaramillo, P.; Samaras, C.; Shiau, C.S.N.; Lave, L.B. Valuation of Plug-In Vehicle Life-Cycle Air Emissions and Oil Displacement Benefits. Proc. Natl. Acad. Sci. USA 2011, 108, 16554-16558. [CrossRef] [PubMed]

65. Notter, D.A.; Gauch, M.; Widmer, R.; Wager, P.; Stamp, A.; Zah, R.; Althaus, H.J. Contribution of Li-Ion Batteries to the Environmental Impact of Electric Vehicles. Environ. Sci. Technol. 2010, 44, 6550-6556. [CrossRef]

66. Eurostat 2019. New Registrations of Passenger Cars by Type of Motor Energy [road_eqr_carpda]. Available online: https://appsso.eurostat.ec.europa.eu/nui/show.do?dataset=road_eqr_carpda\&lang=en (accessed on 29 August 2019).

67. Taxing Energy Use (TEU). 2015. Available online: https://www.oecd-ilibrary.org/taxation/taxing-energy-use -2015_9789264232334-en (accessed on 29 August 2019).

68. Taxing Energy Use (TEU). 2018. Available online: https://www.oecd-ilibrary.org/taxation/taxing-energy-use -2018_9789264289635-en (accessed on 29 August 2019).

(C) 2020 by the authors. Licensee MDPI, Basel, Switzerland. This article is an open access article distributed under the terms and conditions of the Creative Commons Attribution (CC BY) license (http://creativecommons.org/licenses/by/4.0/). 